University of South Florida

DIGITAL COMMONS Digital Commons @ University of @ UNIVERSITY OF SOUTH FLORIDA South Florida

8-1-2014

\title{
Investigation, Quantification and Recommendations - Performance of Alternatively Fueled Buses
}

CUTR

Follow this and additional works at: https://digitalcommons.usf.edu/cutr_nctr

\section{Recommended Citation}

"Investigation, Quantification and Recommendations - Performance of Alternatively Fueled Buses," National Center for Transit Research (NCTR) Report No. CUTR-NCTR-RR-2013-08, Center for Urban Transportation Research, University of South Florida, 2014.

DOI: https://doi.org/10.5038/CUTR-NCTR-RR-2013-08

Available at: https://scholarcommons.usf.edu/cutr_nctr/83

This Technical Report is brought to you for free and open access by the National Center for Transit Research (NCTR) Archive (2000-2020) at Digital Commons @ University of South Florida. It has been accepted for inclusion in Research Reports by an authorized administrator of Digital Commons @ University of South Florida. For more information, please contact digitalcommons@usf.edu. 


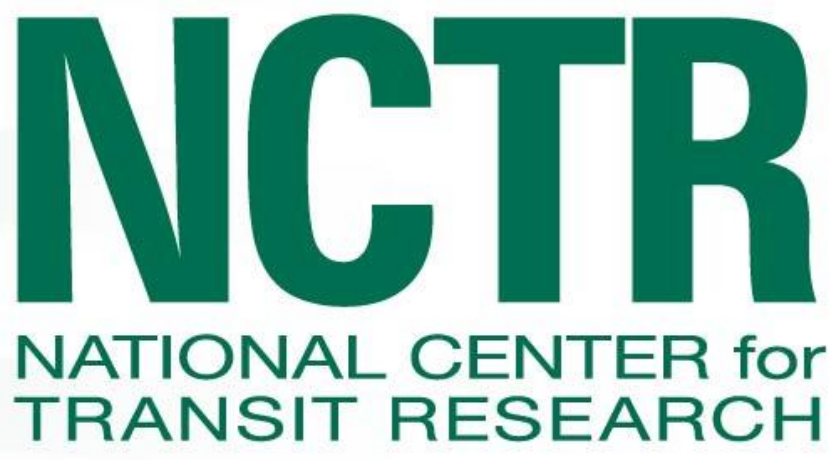

\title{
Investigation, Quantification, and Recommendations - Performance of Alternatively Fueled Buses
}

\author{
Final Report
}

August 2014

PROJECT NO.

FDOT BDV26-977-01

PREPARED FOR

Florida Department of Transportation

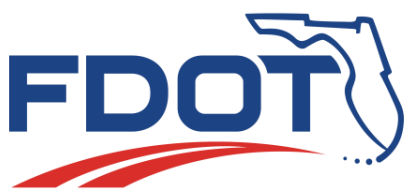




\title{
Investigation, Quantification, and Recommendations - Performance of Alternatively Fueled Buses
}

\author{
FDOT BDV26-977-01
}

Prepared for:

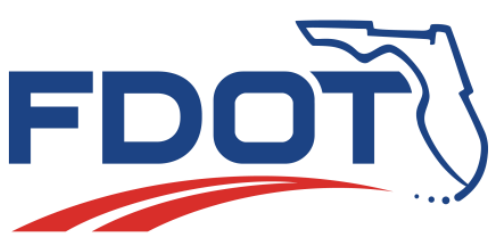

Florida Department of Transportation Robert E. Westbrook, Project Manager

Prepared by:

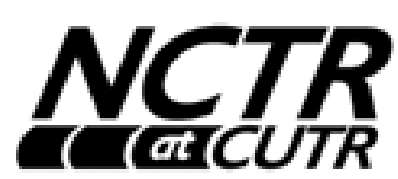

National Center for Transit Research Center for Urban Transportation Research University of South Florida

Stephen L. Reich, PI, Program Director

Alexander Kolpakov, Co-PI, Research Associate

Final Report

August 2014 


\section{Disclaimer}

The contents of this report reflect the views of the authors, who are responsible for the facts and the accuracy of the information presented herein. This document is disseminated under the sponsorship of the Department of Transportation's University Transportation Centers Program, in the interest of information exchange. The U.S. Government assumes no liability for the contents or use thereof.

The opinions, findings, and conclusions expressed in this publication are those of the authors and not necessarily those of the State of Florida Department of Transportation. 


\section{Metric Conversion}

\begin{tabular}{|c|c|c|c|c|}
\hline SYMBOL & WHEN YOU KNOW & MULTIPLY BY & TO FIND & SYMBOL \\
\hline \multicolumn{5}{|c|}{ LENGTH } \\
\hline in & inches & 25.4 & millimeters & $\mathrm{mm}$ \\
\hline ft & feet & 0.305 & meters & $\mathrm{m}$ \\
\hline yd & yards & 0.914 & meters & $\mathrm{m}$ \\
\hline mi & miles & 1.61 & kilometers & $\mathrm{km}$ \\
\hline \multicolumn{5}{|c|}{ VOLUME } \\
\hline fl oz & fluid ounces & 29.57 & milliliters & $\mathrm{mL}$ \\
\hline gal & gallons & 3.785 & liters & L \\
\hline $\mathrm{ft}^{3}$ & cubic feet & 0.028 & cubic meters & $\mathrm{m}^{3}$ \\
\hline$y d^{3}$ & cubic yards & 0.765 & cubic meters & $\mathrm{m}^{3}$ \\
\hline \multicolumn{5}{|c|}{ NOTE: volumes greater than $1000 \mathrm{~L}$ shall be shown in $\mathrm{m}^{3}$} \\
\hline \multicolumn{5}{|c|}{ MASS } \\
\hline $\mathbf{o z}$ & ounces & 28.35 & grams & $g$ \\
\hline lb & pounds & 0.454 & kilograms & $\mathrm{kg}$ \\
\hline $\mathbf{T}$ & short tons $(2000 \mathrm{lb})$ & 0.907 & $\begin{array}{c}\text { megagrams } \\
\text { (or "metric ton") }\end{array}$ & Mg (or "t") \\
\hline \multicolumn{5}{|c|}{ TEMPERATURE (exact degrees) } \\
\hline${ }^{\circ} \mathbf{F}$ & Fahrenheit & $\begin{array}{c}5(F-32) / 9 \\
\text { or }(F-32) / 1.8\end{array}$ & Celsius & ${ }^{\circ} \mathrm{C}$ \\
\hline
\end{tabular}




\section{Technical Report Documentation}

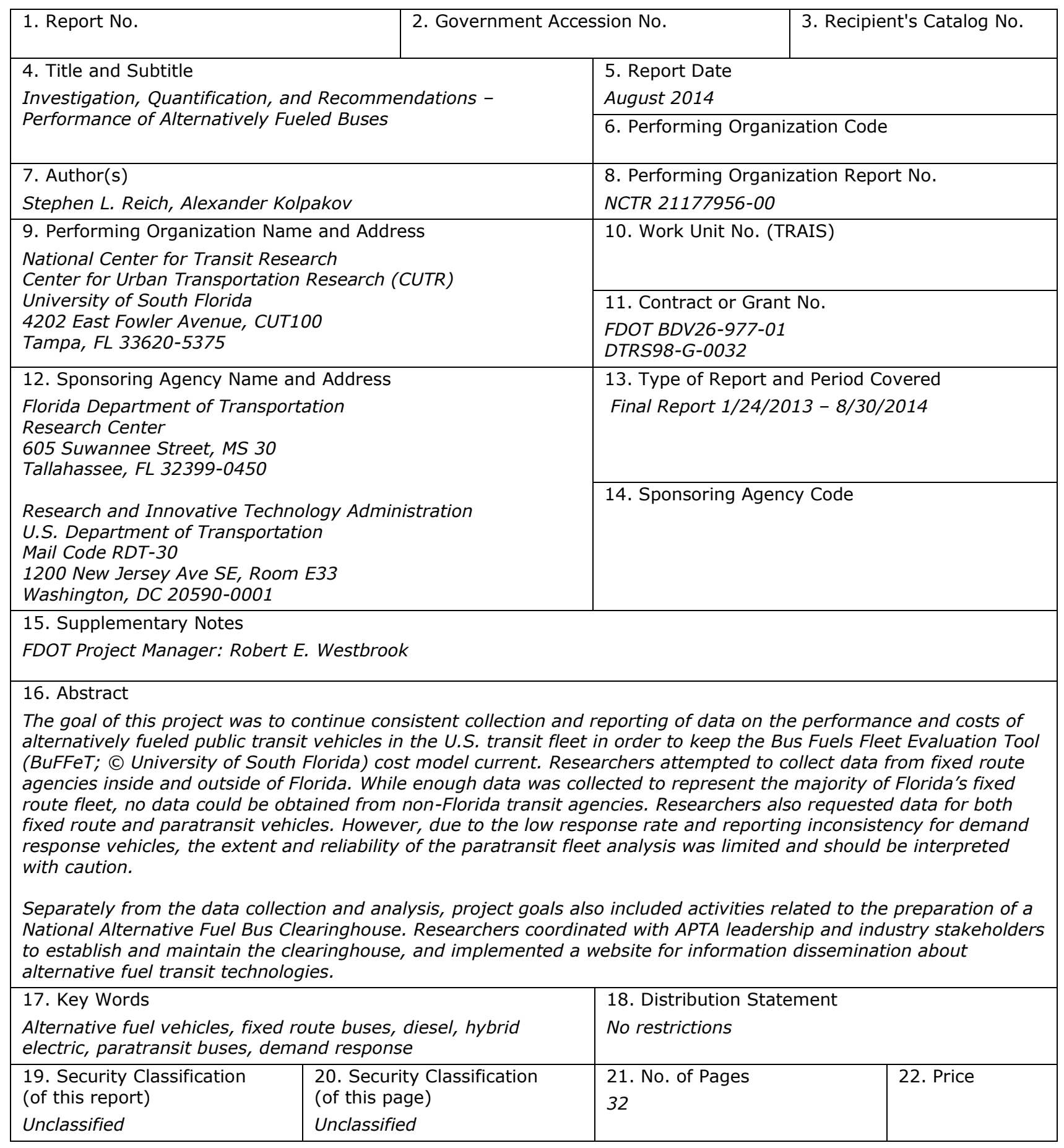




\section{Executive Summary}

Florida transit agencies have been dealing with volatile fuel prices and changes in regulations regarding diesel engines and fuel. In addition, emphasis on reducing the overall consumption of fossil fuels has increased, as well as reducing carbon emissions by transit agencies. Florida transit agencies and funding entities continue to be under pressure to reduce operating costs and to run a more sustainable and environmentally friendly fleet in the urban environment. A popular strategy to pursue these goals has been the acquisition of alternatively fueled buses. However, higher reliance on alternative fuels has increased both capital and operating costs for some fixed route operators, and has created challenges for the widespread adoption of advanced transit technologies.

The Florida Department of Transportation (FDOT) is interested in collecting and analyzing up-to-date data on alternative fuel vehicle performance to assist the department with evaluating the benefits and investment costs in advanced transit technologies. The department engaged the Center for Urban Transportation Research (CUTR) at the University of South Florida (USF) in 2009 and again in 2012 to establish a reporting system for the collection of transit fleet performance and cost data. FDOT is interested in continuing regular data collection, monitoring, and evaluating field data on the performance and operating costs of alternative fuel transit vehicles nationwide. These data will keep the previously developed Bus Fuels Fleet Evaluation Tool (BuFFeT; (c) University of South Florida) life cycle cost model current and useful for decision makers considering investment in alternative fuel transit technologies.

CUTR sent data submission requests to all fixed route transit agencies in Florida. In addition, researchers reached out to the American Public Transportation Association's (APTA) leadership and individual members for their advice and support with data collection from agencies outside of Florida. An attempt was made to collect data covering both fixed route and demand response transit vehicles. Unfortunately, regardless of the continued efforts to maintain regular data reporting, the response rate to these data requests was less than ideal.

Despite difficulties with data collection, CUTR obtained relevant operations and cost data for fixed route buses from eight Florida transit agencies reporting during 2013. However, the reporting was not always regular, with only five agencies providing fleet data almost every quarter of 2013. No data was available from transit agencies outside of Florida.

The data analysis for fixed route buses revealed that the vast majority of Florida's transit buses are regular diesel vehicles (89 percent of the reported fleet), while only 11 percent are alternative fuel vehicles (diesel hybrids). More than 79 percent of the diesel buses are 40-foot buses, with 35-foot and 32-foot buses representing 6.8 percent and 6.3 percent of the diesel fleet, respectively. Alternative fuel buses, on the other hand, are more likely to be larger in size than diesel buses. Sixty-foot articulated buses represent 26.5 percent of diesel hybrid vehicles, while 40 -foot buses account for 38.6 percent of the diesel hybrid fleet.

The analysis of fixed route data showed that alternative fuel buses have significantly higher acquisition costs but offer better fuel mileage than diesel buses. In addition, hybrid buses 
tend to have lower parts costs and maintenance costs per mile than comparable diesel buses. A 40-foot diesel hybrid bus has 21.6 percent better fuel economy $(4.45 \mathrm{mpg}$ for hybrid vs. $3.66 \mathrm{mpg}$ for diesel), 71.2 percent lower parts cost per mile $(\$ 0.120 / \mathrm{mile}$ for hybrid vs. $\$ 0.417 /$ mile for diesel), and 87.4 percent lower maintenance cost per mile ( $\$ 0.124 /$ mile for hybrid vs. $\$ 0.985$ for diesel), compared to a regular diesel bus. At the same time, a 40 -foot diesel hybrid bus costs 66.2 percent more to acquire than a comparable diesel bus.

The aggregate comparison of performance and maintenance costs of traditional diesel buses and hybrid buses operated by Florida fixed route agencies revealed that hybrid buses, regardless of vehicle size, have 21.0 percent better fuel economy, 66.2 percent lower parts cost per mile, and 72.2 percent lower maintenance cost per mile. However, hybrid buses on average cost 67.0 percent more to acquire than traditional diesel buses. The differential in performance can be attributed at least partially to the average age of the vehicles. An average diesel hybrid bus in the current analysis is 2.9 years old, compared to 8.4 years for an average diesel bus. Newer buses typically perform better and cost less to operate and maintain.

Slightly different results were observed when weighted averages were used to calculate miles per gallon and cost per mile in order to account for potential differences in miles driven by the various buses in the data sample. The use of weighted averages noticeably changes the analysis results, most notably for 40-foot buses, reducing the differential in fuel and cost efficiency between diesel and diesel hybrid vehicles. When accounting for miles driven, 40-foot hybrid buses demonstrate 8.6 percent better fuel mileage (compared to 21.6 percent when miles driven are not considered), 38.9 percent lower parts cost per mile (compared to 71.2 percent when simple averages are used), and 69.7 percent lower maintenance costs per mile (compared to 87.4 percent when simple averages are used).

The observed results may indicate that a relatively large number of hybrid buses in the dataset are earlier-generation vehicles with lower fuel efficiency, which have been in use for some time and have logged a lot of mileage. The dataset also contains a large number of older, high-mileage diesel buses that perform exceptionally well. As newer, more efficient diesel hybrid buses are driven more miles and the number of later-generation hybrids in the dataset increases, the average fuel efficiency of the hybrid buses will improve.

CUTR also collected a limited data sample on the paratransit fleet, covering 60 demand response vehicles over the course of the project. Thirty percent of the demand response fleet consists of gasoline-powered vehicles, 3.3 percent ( 2 vehicles) are diesel hybrids, and the power plant of the remaining 66.7 percent of the paratransit fleet is not known (i.e., was not reported). The available data indicate that hybrid paratransit vehicles demonstrate 23.1 percent better fuel mileage, 25.0 percent lower parts cost per mile, and 84.3 percent lower maintenance cost per mile than comparable gasoline-powered vehicles. Due to the extremely small data sample and significant gaps in the paratransit data, the extent of the analysis as well as the reliability of the comparison are far from optimal.

The intent of the current analysis was to contribute to the ongoing evaluation of the costs and benefits of investment in advanced transit technologies, rather than to recommend 
particular alternative fuel technologies. Additionally, since the analysis was based on a limited data sample, the results should be treated with caution. It is suggested to continue collecting data from transit service providers on the performance and life cycle costs of alternative fuel vehicles. As more field data are collected, the reliability of the analysis will improve.

To encourage agencies to regularly submit data, consideration should be given to incorporating this reporting requirement into existing nationwide transit data collection efforts, such as the Public Transportation Vehicle Database administered by APTA and/or the National Transit Database maintained by the Federal Transit Administration (FTA). Implementing an online data collection tool would also facilitate regular data submission by transit agencies, and would simplify storage, handling, and data analysis.

Separately from the data collection and analysis, researchers engaged in discussions and activities related to the preparation of a National Alternative Fuel Bus Clearinghouse. As part of this effort, CUTR developed the Advanced Transit Energy Portal (ATEP) website, a singlepoint source of information related to the operation of alternative fuel buses and technologies in the U.S. transit fleet. The website provides up-to-date articles and features the latest developments in various alternative fuel technologies, transit agency news, and U.S. transit agencies' experience with operating alternative fuel vehicles in their fleets, including identified advantages and limitations, lessons learned, best practices and critical success factors, and research results. Funded by a supplemental federal grant from the National Center for Transit Research (NCTR), this effort closely relates to the initiatives undertaken for this project. 


\section{Table of Contents}

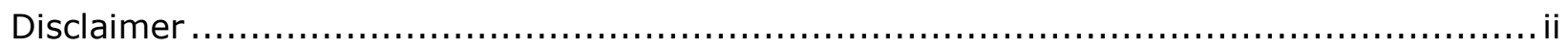

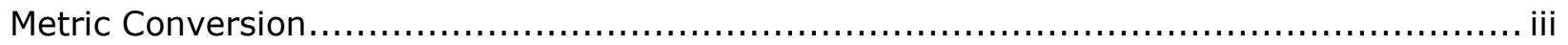

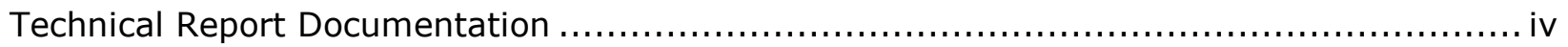

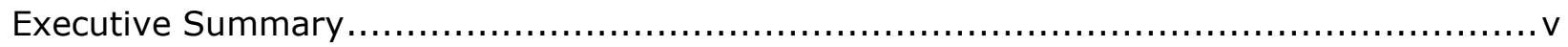

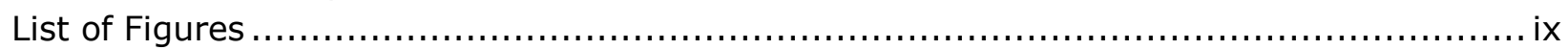

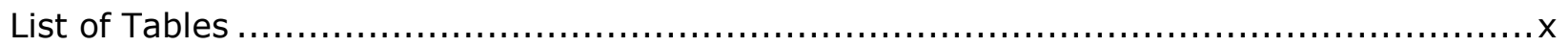

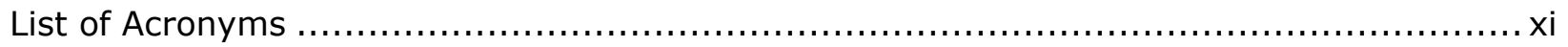

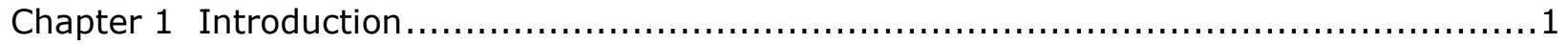

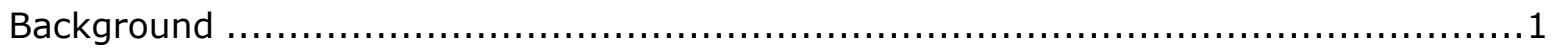

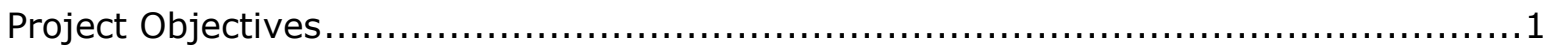

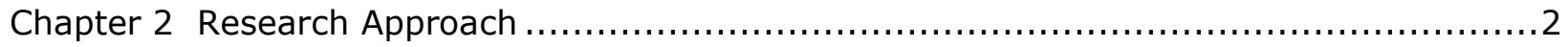

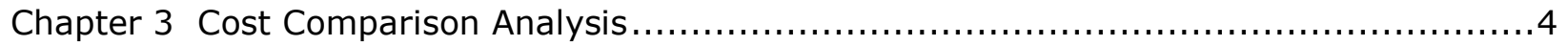

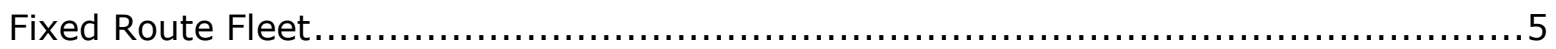

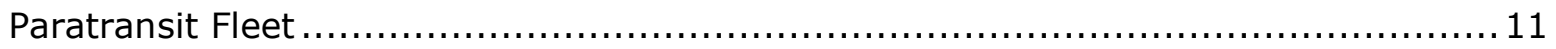

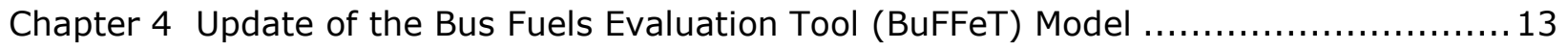

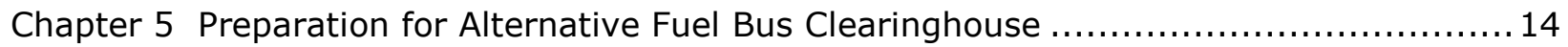

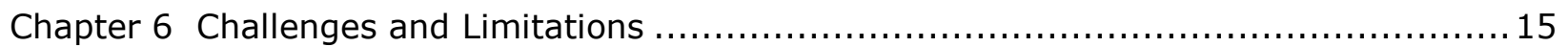

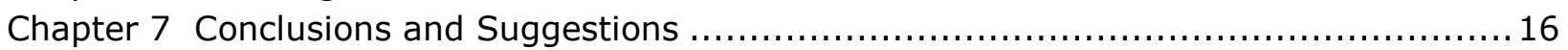

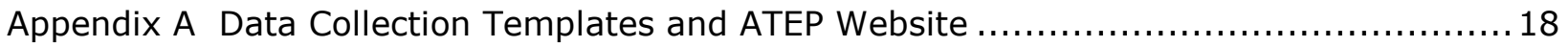




\section{List of Figures}

Figure 3-1. Diesel and diesel hybrid fleet composition by vehicle size........................ 5

Figure 3-2. Comparison of performance and costs of 40 -foot buses, diesel vs. hybrid. .......7

Figure 3-3. Comparison of performance and costs of 60 -foot buses, diesel vs. hybrid. .......7

Figure 3-4. Comparison of diesel vs. diesel hybrid, all vehicle sizes. ........................ 8

Figure 3-5. Weighted cost and performance comparison for 40 -foot buses. .................. 10

Figure 3-6. Weighted comparison - diesel vs. diesel hybrid buses of all sizes................. 11

Figure 3-7. Comparison of diesel hybrid vs. gasoline paratransit vehicles. ................... 12

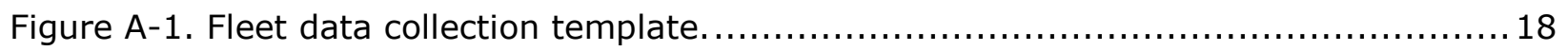

Figure A-2. Proposed ATEP sample data collection page. ................................ 19

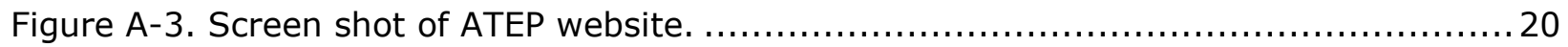




\section{List of Tables}

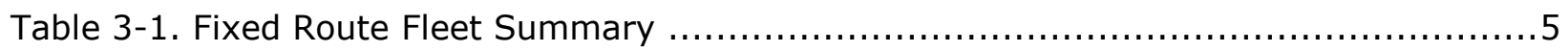

Table 3-2. Cost and Performance Comparison of Fixed Route Fleet ............................6

Table 3-3. Aggregate Comparison of Different Transit Vehicle Power Plants ...................8

Table 3-4. Fixed Route Cost and Performance Comparison - Weighted Parameters...........9

Table 3-5. Fixed Route Aggregate Comparison - Weighted Parameters ....................... 10

Table 3-6. Comparison of Paratransit Vehicles with Different Power Plants.................... 11 


\section{List of Acronyms}

$\begin{array}{ll}\text { ABBG } & \text { American Bus Benchmarking Group } \\ \text { APTA } & \text { American Public Transportation Association } \\ \text { ARRA } & \text { American Recovery and Reinvestment Act of } 2009 \\ \text { ATEP } & \text { Advanced Transit Energy Portal } \\ \text { BRT } & \text { Bus Rapid Transit } \\ \text { BuFFeT } & \text { Bus Fuels Fleet Evaluation Tool } \\ \text { CUTR } & \text { Center for Urban Transportation Research } \\ \text { FDOT } & \text { Florida Department of Transportation } \\ \text { NCTR } & \text { National Center for Transit Research } \\ \text { TIGGER } & \text { Transit Investments for Greenhouse Gas and Energy Reduction }\end{array}$




\section{Chapter 1 \\ Introduction}

\section{Background}

Funding made available through the federal economic stimulus effort known as the American Recovery and Reinvestment Act of 2009 (ARRA) has aided growth in the acquisition of alternative fuel transit vehicles. Some Florida agencies are receiving funding through the Transit Investments for Greenhouse Gas and Energy Reduction (TIGGER) grant program (part of ARRA), while others are using regular transit capital funds. Typically, FDOT funds 50 percent of the non-federal share of bus capital acquisition. Pressure on agencies to procure and on Florida Department of Transportation (FDOT) to fund alternatively fueled buses has escalated with the enormous push toward compressed natural gas as a domestically produced urban fleet fuel.

The National Center for Transit Research (NCTR) and FDOT have funded efforts in the last few years to gain a better understanding of the true life cycle costs and operational issues associated with shifting a fixed route bus system from traditional diesel-powered units to vehicles with a different power plant. The acquisition, maintenance, and operating data collected on Florida's fixed route fleet provide FDOT and agencies with up-to-date information to assist in procurement or funding decisions. FDOT is interested in continuing this effort to collect and maintain updated information on the performance and costs of alternative fuel vehicles as both the department and local transit agencies evaluate the benefits and costs of investment in advanced transit technologies.

Recently, a life cycle cost model (BuFFeT(C) was developed using data from fleets across the United States. Researchers obtained detailed data on nearly 5,000 heavy-duty buses, giving Florida agencies knowledge of cost and maintenance experiences for technologies that had not been widely used or for which few units were in service in Florida. These data have not been updated since 2009. As technology has improved and agencies have gained more experience with operating alternatively fueled vehicles, another effort to collect new data would create a more reliable Florida database for decision support.

\section{Project Objectives}

The main research objectives for this project included the following:

1. Collect a large sample of maintenance, parts, and energy usage of heavy-duty urban transit fleets in the U.S. to facilitate an ongoing life cycle cost evaluation of vehicles of various propulsion types.

2. Create a statistically reliable database to assess investment in energy-efficient public transportation vehicles and to keep the Bus Fuels Fleet Evaluation Tool (BuFFeT(C) cost model current.

3. Provide policy makers with recent and reliable data on fuel and maintenance savings resulting from investments in non-traditionally fueled or powered heavy-duty buses.

4. Assess the willingness of transit agencies across the U.S. to participate in a proposed National Alternative Fuel Bus Clearinghouse. 


\section{Chapter 2 Research Approach}

As a first step, CUTR conducted a literature review of the existing alternative technologies and fuels currently used on public transit vehicles, including their advantages, limitations, and costs. The results of that analysis were summarized and provided to the project manager as a separate deliverable, focusing mostly on the cost comparison between commonly used propulsion systems and fuels, rather than detailed technical differences between technologies.

Researchers then contacted fixed route transit service providers around the country to solicit operations and cost data on the performance of alternative fuel vehicles in their fleets, using a brief spreadsheet table developed under a previous NCTR project (FDOT BDK85-977-18) as the data collection tool. To facilitate data collection, agencies were offered the option to report data in any format other than the suggested reporting tool that was more convenient to them. The data collected included agency name, unit number, vehicle length, power plant, fuel type, duty cycle, date placed in service, acquisition cost, warranty status, life-to-date mileage, life-to-date fuel usage, life-to-date parts costs, and life-to-date labor costs. Appendix A contains the data collection template.

CUTR sent data submission requests to all fixed route transit agencies in Florida requesting their assistance. Researchers also contacted the leadership and individual members of the American Public Transportation Association (APTA), seeking their advice and assistance in data collection from agencies outside of Florida. Agencies were requested to report quarterly on their entire fleet, both alternative and traditionally fueled. After the data collection mailouts, CUTR followed up with phone calls to encourage submissions. In coordination with the project manager, researchers sent transit agencies regular reminders to submit operations and maintenance cost data for their fleets.

Regardless of the efforts by researchers to collect the data, and requests by the FDOT project manager to assist CUTR, response was less than ideal. During the calendar year 2013, eight transit agencies provided relevant fleet maintenance and cost data, including Palm Tran (Palm Beach), StarMetro (Tallahassee), MDT (Miami), Broward County Transit (Broward County), LAMTD (Lakeland), Votran (Volusia County), Pasco County Public Transit (Pasco County), and JTA (Jacksonville). In addition, only one of the agencies that provided quarterly data reported it consistently (i.e., every quarter), with four agencies reporting almost every quarter throughout the year. Nevertheless, having relatively regular reporting by a few major state transit agencies, with a significant number of vehicles, made it possible to assemble a dataset covering the majority of Florida's fixed route fleet. No out-ofstate agencies reported meaningful operations and cost data.

Researchers used the collected data to analyze the costs involved in operating alternative fuel vehicles in the transit fleet. The analysis results were submitted to the project manager in the form of quarterly summary reports that compared field performance and costs across different transit propulsion technologies. 
These data were also used to update the previously developed, and funded by FDOT, cost model known as the BuFFeTC (Bus Fuels Fleet Evaluation Tool). Keeping the model populated with the latest data enables accurate performance assessment of the various transit power plants, and preserves the model's value as a decision support tool for policy makers considering the costs and benefits of investing in alternative propulsion transit vehicles in Florida.

Using the same reporting tool as for the fixed route fleet, CUTR attempted to collect operating and cost data for demand response vehicles. All fixed route agencies running paratransit operations were requested to report paratransit data separately from the fixed route vehicles.

Unlike fixed route, the data for paratransit vehicles was limited and not reported consistently. CUTR collected data for 60 demand response vehicles in the state during 2013. Of these vehicles, only 17 were reported consistently (every quarter), providing the complete cost and performance data as requested.

In consultation with APTA, researchers also developed a formalized data collection tool and started developing an online reporting system to allow agencies to input data electronically on fleet performance and costs. This electronic data submission tool is expected to facilitate data collection from transit agencies nationwide, and improve participation and reporting consistency in the future.

Finally, apart from the data collection and analysis, CUTR engaged in discussions and activities related to the preparation of a National Alternative Fuel Bus Clearinghouse. Various initiatives included coordination with APTA leadership and industry stakeholders regarding establishing and maintaining the clearinghouse, as well as implementing the website for information dissemination concerning alternative fuel technologies. 


\section{Chapter 3 \\ Cost Comparison Analysis}

The Florida Department of Transportation (FDOT) engaged CUTR to collect and report performance and cost data related to the operation and maintenance of transit vehicles in the United States. CUTR made repeated attempts to collect performance and cost data for both fixed route and paratransit vehicle fleets. Recognizing the difference between the two types of service, researchers performed the data collection separately for fixed route buses and paratransit buses. Consequently, the costs were also reported separately for these two types of transit service. Researchers sent several data requests and data submission reminders to all Florida transit agencies. Attempts were also made to collect fleet operation and maintenance cost data from agencies outside Florida.

While CUTR was able to collect operating cost data for the majority of fixed route buses in the state, the paratransit fleet data were limited. The analysis presented in the current report therefore focused primarily on the fixed route fleet. The paratransit fleet analysis should be interpreted with caution.

Some agencies reported their data consistently every quarter during 2013, while others reported only in certain quarters. For the purposes of the current analysis, and in order to overcome the limitations of inconsistent reporting, researchers assembled a dataset covering all the vehicles reported in 2013, regardless of whether the vehicles were reported each quarter. Since agencies submitted the fleet statistics on a to-date basis, the latest quarter in which the agency reported data was used to perform the annual analysis. The following agencies provided fleet operation and maintenance cost data for at least one quarter during 2013:

1. Palm Tran (Palm Beach)

2. StarMetro (Tallahassee)

3. MDT (Miami)

4. Broward County Transit (Broward County)

5. Lakeland Area Mass Transit District (LAMTD, Lakeland)

6. PCPT (Pasco County)

7. Votran (Volusia County)

8. JTA (Jacksonville)

The 2013 data covers 1,490 fixed route vehicles and 60 demand response vehicles. The summary statistics presented in this document are based on the cost data from these transit agencies. 


\section{Fixed Route Fleet}

Table 3-1 presents a summary of the physical characteristics of the fixed route transit fleet.

Table 3-1. Fixed Route Fleet Summary

\begin{tabular}{|l|r|r|}
\hline Power Plant & \multicolumn{1}{|c|}{ Length } & Number of Buses \\
\hline \multirow{4}{*}{ Diesel } & Unknown & 40 \\
\cline { 2 - 3 } & $25^{\prime}$ & 5 \\
\cline { 2 - 3 } & $29^{\prime}$ & 8 \\
\cline { 2 - 3 } & $30^{\prime}$ & 17 \\
\cline { 2 - 3 } & $32^{\prime}$ & 90 \\
\cline { 2 - 3 } & $35^{\prime}$ & 83 \\
\cline { 2 - 3 } & $40^{\prime}$ & 1,048 \\
\cline { 2 - 3 } & $45^{\prime}$ & 12 \\
\hline \multirow{4}{*}{ Diesel Hybrid } & $60^{\prime}$ Articulated & 18 \\
\cline { 2 - 3 } & Unknown & 15 \\
\cline { 2 - 3 } & $32^{\prime}$ & 1 \\
\cline { 2 - 3 } & $40^{\prime}$ & 64 \\
\cline { 2 - 3 } & $41^{\prime}$ & 13 \\
\cline { 2 - 3 } & $62^{\prime}$ Articulated & 29 \\
\hline Trolley & Unknown & 44 \\
\hline Total Fleet & & $\mathbf{1 , 4 9 0}$ \\
\hline
\end{tabular}

Almost 89.0 percent ( 1,321 buses) of the reported fixed route fleet consists of regular diesel buses, about 11.1 percent (166 buses) are diesel hybrids, and 0.2 percent ( 3 vehicles) are trolleys. The responding agencies reported no other transit vehicle fuel/propulsion types. The current report concentrates primarily on the comparison between diesel and diesel hybrid buses, as these are the major propulsion types in transit fleets. Due to a small number of vehicles, trolleys were not used in the fleet comparison. Figure 3-1 shows the comparison of diesel and diesel hybrid fixed route fleets by size.

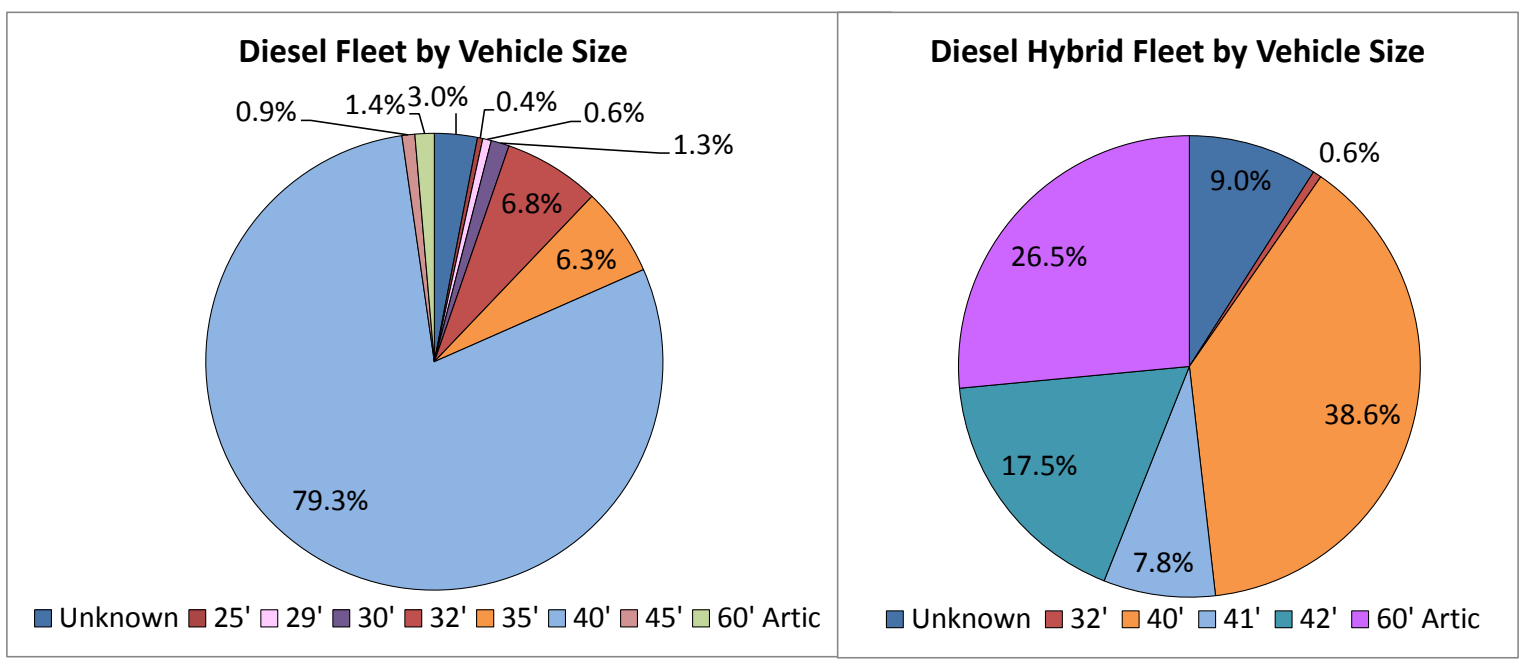

Figure 3-1. Diesel and diesel hybrid fleet composition by vehicle size. 
More than 79 percent of the diesel buses are 40-foot buses. Thirty-two-foot and 35-foot buses represent 6.8 percent and 6.3 percent of the diesel fleet, respectively. Larger 60 -foot articulated buses account for only 1.4 percent of the diesel fleet.

Unlike diesel buses, 60-foot articulated buses represent a large share of the diesel hybrid fleet. Sixty-foot articulated buses represent 26.5 percent of diesel hybrid vehicles, while 40-foot buses account for 38.6 percent of the diesel hybrid fleet. Forty-one-foot and 42 -foot buses represent 7.8 percent and 17.5 percent of the diesel hybrid fleet, respectively.

Table 3-2 provides a detailed cost and performance comparison of transit buses. For comparison purposes, reported vehicle acquisition costs have been adjusted using the Consumer Price Index (CPI), reported by the U.S. Bureau of Labor Statistics (BLS), and are presented in constant 2013 dollars.

Table 3-2. Cost and Performance Comparison of Fixed Route Fleet

\begin{tabular}{|c|c|c|c|c|c|c|c|c|}
\hline $\begin{array}{l}\text { Power } \\
\text { Plant }\end{array}$ & Length & $\begin{array}{c}\text { Number } \\
\text { of } \\
\text { Buses }\end{array}$ & $\begin{array}{c}\text { Average } \\
\text { Age } \\
\text { (Years) }\end{array}$ & $\begin{array}{c}\text { Average } \\
\text { Acquisition } \\
\text { Cost }\end{array}$ & $\begin{array}{c}\text { Fuel } \\
\text { Mileage } \\
\text { (MPG) }\end{array}$ & $\begin{array}{c}\text { Parts } \\
\text { Cost } \\
\text { per } \\
\text { Mile } \\
\end{array}$ & $\begin{array}{l}\text { Maintenance } \\
\text { Cost per Mile }\end{array}$ & $\begin{array}{c}\text { Total } \\
\text { Operating } \\
\text { Cost per } \\
\text { Mile }\end{array}$ \\
\hline \multirow{9}{*}{ Diesel } & Unknown & 40 & 9.8 & & 3.53 & $\$ 0.879$ & $\$ 0.303$ & $\$ 1.182$ \\
\hline & $25^{\prime}$ & 5 & 10.4 & $\$ 137,783$ & & & & \\
\hline & $29^{\prime}$ & 8 & 6.7 & $\$ 357,133$ & 4.36 & $\$ 0.208$ & $\$ 0.234$ & $\$ 0.444$ \\
\hline & $30^{\prime}$ & 17 & 6.9 & $\$ 327,983$ & & $\$ 0.184$ & $\$ 0.174$ & $\$ 0.361$ \\
\hline & $32^{\prime}$ & 90 & 6.1 & $\$ 312,865$ & 4.00 & $\$ 0.730$ & $\$ 1.541$ & $\$ 2.273$ \\
\hline & $35^{\prime}$ & 83 & 6.4 & $\$ 353,636$ & 4.34 & $\$ 0.199$ & $\$ 0.228$ & $\$ 0.427$ \\
\hline & $40^{\prime}$ & 1,048 & 8.8 & $\$ 373,358$ & 3.66 & $\$ 0.417$ & $\$ 0.985$ & $\$ 1.355$ \\
\hline & $45^{\prime}$ & 12 & 7.3 & $\$ 572,276$ & 3.52 & $\$ 0.284$ & $\$ 1.371$ & $\$ 1.658$ \\
\hline & $60^{\prime}$ Artic & 18 & 4.0 & $\$ 671,991$ & 2.67 & $\$ 0.261$ & $\$ 0.197$ & $\$ 0.461$ \\
\hline \multirow{6}{*}{$\begin{array}{l}\text { Diesel } \\
\text { Hybrid }\end{array}$} & Unknown & 15 & 2.8 & & 4.80 & $\$ 0.080$ & $\$ 0.030$ & $\$ 0.109$ \\
\hline & $32^{\prime}$ & 1 & 3.7 & & 6.99 & $\$ 0.340$ & $\$ 1.720$ & $\$ 2.060$ \\
\hline & $40^{\prime}$ & 64 & 2.9 & $\$ 620,664$ & 4.45 & $\$ 0.120$ & $\$ 0.124$ & $\$ 0.243$ \\
\hline & $41^{\prime}$ & 13 & 3.4 & $\$ 585,674$ & 4.63 & $\$ 0.148$ & $\$ 0.949$ & $\$ 1.096$ \\
\hline & $42^{\prime}$ & 29 & 2.2 & $\$ 641,778$ & 4.26 & $\$ 0.242$ & $\$ 0.342$ & $\$ 0.575$ \\
\hline & $60^{\prime}$ Artic & 44 & 3.3 & $\$ 887,317$ & 3.67 & $\$ 0.212$ & $\$ 0.819$ & $\$ 1.032$ \\
\hline Trolley & Unknown & 3 & 12.6 & & 5.01 & $\$ 0.423$ & $\$ 0.157$ & $\$ 0.580$ \\
\hline $\begin{array}{l}\text { Total } \\
\text { Fleet }\end{array}$ & & 1,490 & & & & & & \\
\hline
\end{tabular}

The data show that diesel hybrid buses have significantly higher acquisition cost compared to diesel buses. At the same time, hybrid buses provide better fuel mileage and lower parts cost and maintenance cost per mile than diesel buses. For example, current data indicate that a 40 -foot diesel hybrid bus has 21.6 percent better fuel mileage than a 40 -foot diesel bus (4.45 mpg for diesel hybrid vs. $3.66 \mathrm{mpg}$ for regular diesel). In addition, 40 -foot diesel hybrid buses have 71.2 percent lower parts cost per mile $(\$ 0.120 /$ mile for diesel hybrid vs. $\$ 0.417 /$ mile for diesel), and 87.4 percent lower maintenance cost per mile ( $\$ 0.124 / \mathrm{mile}$ for diesel hybrid vs. $\$ 0.985 /$ mile for diesel), compared to diesel buses. Figure 3-2 graphically 
illustrates the comparison of performance and costs of a 40-foot diesel and a 40-foot diesel hybrid bus.

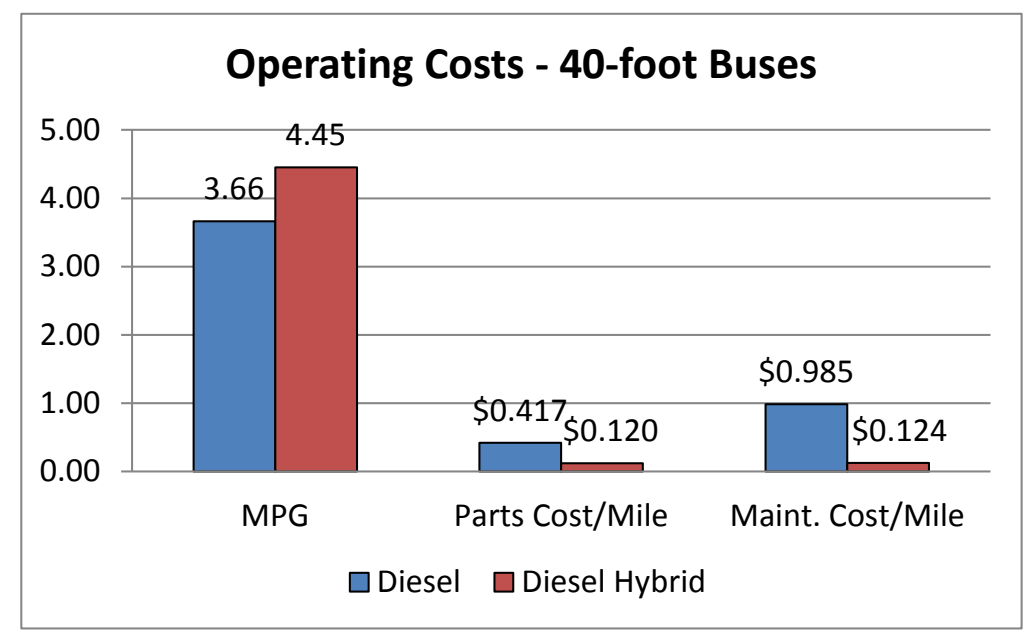

Figure 3-2. Comparison of performance and costs of 40-foot buses, diesel vs. hybrid.

Larger articulated hybrid buses demonstrate better fuel mileage compared to regular diesel buses. A 60-foot articulated diesel hybrid bus has 37.3 percent better fuel mileage than a comparable diesel bus (3.67 mpg for hybrid vs. $2.67 \mathrm{mpg}$ for diesel bus). However, the difference in parts costs per mile between diesel hybrid and regular diesel buses is less substantial for 60 -foot buses than it is for 40 -foot buses. The difference in maintenance cost per mile is actually reversed, favoring diesel. For example, 60-foot articulated hybrid buses have 18.6 percent lower parts cost per mile (compared to 71.2 percent for 40 -foot buses) and 315.4 percent higher maintenance cost per mile (compared to 87.4 percent lower for 40-foot buses) than regular diesel buses. Figure 3-3 illustrates the comparison between 60-foot diesel and 60-foot diesel hybrid buses.

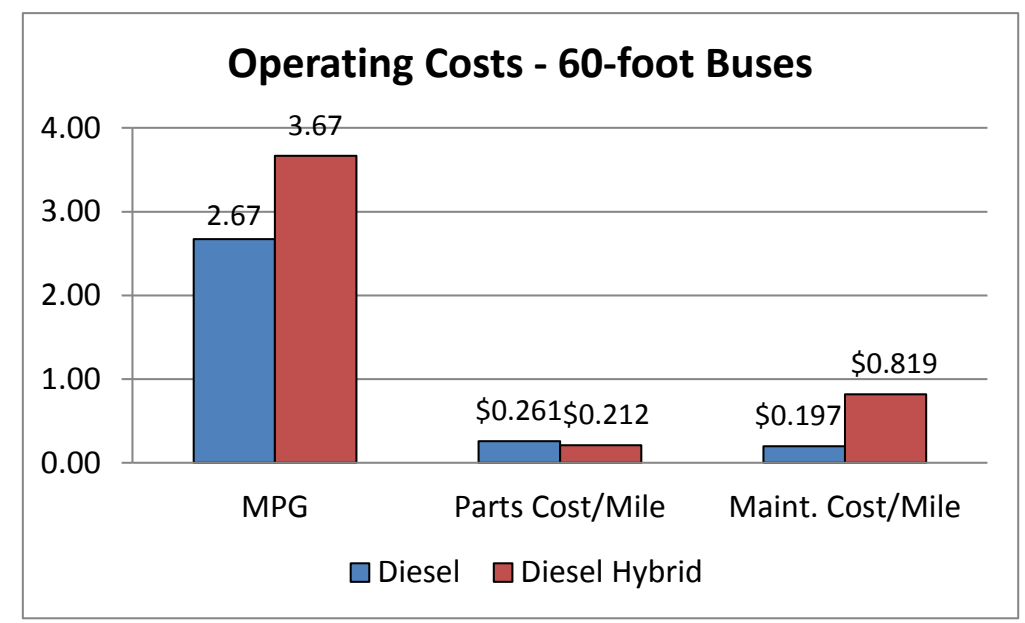

Figure 3-3. Comparison of performance and costs of 60-foot buses, diesel vs. hybrid. 
It must be noted that in this data sample many articulated hybrid buses run Bus Rapid Transit (BRT) routes, while diesel buses are used on regular urban routes. The difference in duty cycles can be a significant factor in explaining the observed variations in fuel mileage. However, the reason for the substantial variation in operating cost per mile for 60 -foot buses, demonstrated by the data, is not clear.

Average vehicle age contributes, at least partially, to the difference in fuel mileage and parts/maintenance costs for hybrid buses. In addition to being more efficient, hybrid buses are newer, with an average age of 2.9 years as reported by the transit agencies. For comparison, the average age of diesel buses operated by the reporting transit agencies is 8.4 years. Newer vehicles typically perform better and cost less to operate than older vehicles.

Table 3-3 presents the comparison of performance and maintenance costs between traditional diesel and diesel hybrid buses at an aggregate level. For proper comparison, reported vehicle acquisition costs have been adjusted to constant 2013 dollars using CPI.

Table 3-3. Aggregate Comparison of Different Transit Vehicle Power Plants

\begin{tabular}{|l|r|r|r|r|r|r|r|}
\hline Power Plant & $\begin{array}{c}\text { Number } \\
\text { of } \\
\text { Buses }\end{array}$ & $\begin{array}{c}\text { Average } \\
\text { Age } \\
\text { (Years) }\end{array}$ & $\begin{array}{c}\text { Average } \\
\text { Acquisition } \\
\text { Cost }\end{array}$ & $\begin{array}{c}\text { Fuel } \\
\text { Mileage } \\
\text { (MPG) }\end{array}$ & $\begin{array}{c}\text { Parts } \\
\text { Cost } \\
\text { per } \\
\text { Mile }\end{array}$ & $\begin{array}{c}\text { Maintenance } \\
\text { Cost per Mile }\end{array}$ & $\begin{array}{c}\text { Total } \\
\text { Operating } \\
\text { Cost per } \\
\text { Mile }\end{array}$ \\
\hline Diesel & 1,321 & 8.4 & $\$ 366,882$ & 3.71 & $\$ 0.438$ & $\$ 0.955$ & $\$ 1.356$ \\
\hline Diesel Hybrid & 166 & 2.9 & $\$ 612,725$ & 4.49 & $\$ 0.148$ & $\$ 0.265$ & $\$ 0.411$ \\
\hline Trolley & 3 & 12.6 & & 5.01 & $\$ 0.423$ & $\$ 0.157$ & $\$ 0.580$ \\
\hline Total Fleet & $\mathbf{1 , 4 9 0}$ & $\mathbf{7 . 8}$ & $\mathbf{\$ 3 7 6 , 8 5 2}$ & $\mathbf{3 . 7 8}$ & $\mathbf{\$ 0 . 4 1 3}$ & $\mathbf{\$ 0 . 8 9 1}$ & $\mathbf{\$ 1 . 2 7 1}$ \\
\hline
\end{tabular}

Note: Articulated buses were excluded as outliers from the calculation of acquisition costs, fuel mileage, and costs per mile.

The data show that diesel hybrid buses, regardless of size, on average have 21.0 percent better fuel economy, 66.2 percent lower parts cost per mile, and 72.2 percent lower maintenance cost per mile than regular diesel buses. At the same time, diesel hybrid buses on average cost about 67.0 percent more to acquire than comparable diesel vehicles. Figure 3-4 illustrates the comparison between diesel and diesel hybrid buses of all sizes.

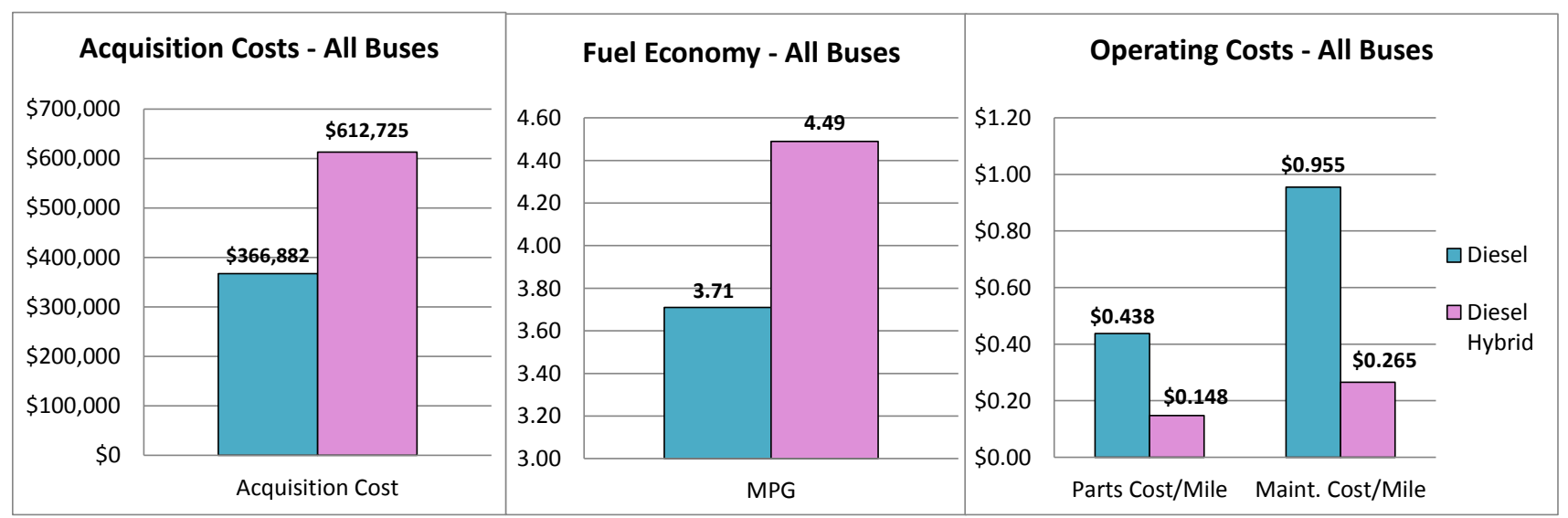

Figure 3-4. Comparison of diesel vs. diesel hybrid, all vehicle sizes. 
These results, however, should be interpreted with caution since some cost differential may be attributed to hybrid buses being newer vehicles (average age 2.9 years), rather than the differences in performance of different power plants (diesel vs. hybrid). In addition, agencies prefer using hybrid buses for BRT routes that typically entail higher speeds and fewer stops. Therefore, duty cycle differences rather than propulsion technology account for some of the performance variation between diesel hybrid and regular diesel buses. Finally, the estimates for hybrid buses are based on a limited number of data points (only 166 vehicles out of 1,490 reported are diesel hybrid buses), limiting the robustness of the analysis. As more data are collected on the performance and maintenance costs of alternative fuel transit vehicles, the reliability of the analysis will improve.

One potential flaw of the methodology used for the analysis could also include employing simple averages for calculating fuel mileage and costs per mile. This approach ignores the differences between miles driven by each bus and may result in incorrect calculations, especially when the miles driven by various types of buses vary significantly. To account for the difference in mileage, using weighted averages for calculating MPG and costs per mile is warranted. Calculating weighted averages rather than simple averages allows assigning higher weights to the calculated parameters that are based on higher mileage, thus allowing them a higher influence on the final estimate. Table 3-4 presents a detailed performance and cost comparison of the transit buses, where the calculated parameters (MPG and costs per mile) are weighted by the mileage driven by each bus.

Table 3-4. Fixed Route Cost and Performance Comparison - Weighted Parameters

\begin{tabular}{|c|c|c|c|c|c|c|}
\hline $\begin{array}{l}\text { Power } \\
\text { Plant }\end{array}$ & Length & $\begin{array}{c}\text { Number } \\
\text { of } \\
\text { Buses }\end{array}$ & $\begin{array}{c}\text { MPG } \\
\text { (Weighted)* }\end{array}$ & $\begin{array}{c}\text { Parts Cost } \\
\text { per Mile } \\
\text { (Weighted)* }\end{array}$ & $\begin{array}{c}\text { Maintenance } \\
\text { Cost per } \\
\text { Mile } \\
\text { (Weighted)* } \\
\end{array}$ & $\begin{array}{c}\text { Total Cost } \\
\text { per Mile } \\
\text { (Weighted)* }\end{array}$ \\
\hline \multirow{9}{*}{ Diesel } & Unknown & 40 & 3.88 & $\$ 0.256$ & $\$ 0.061$ & $\$ 0.316$ \\
\hline & $25^{\prime}$ & 5 & & & & \\
\hline & $29^{\prime}$ & 8 & 4.33 & $\$ 0.191$ & $\$ 0.260$ & $\$ 0.451$ \\
\hline & $30^{\prime}$ & 17 & & $\$ 0.201$ & $\$ 0.155$ & $\$ 0.356$ \\
\hline & $32^{\prime}$ & 90 & 4.13 & $\$ 0.621$ & $\$ 1.370$ & $\$ 1.991$ \\
\hline & $35^{\prime}$ & 83 & 4.33 & $\$ 0.199$ & $\$ 0.179$ & $\$ 0.377$ \\
\hline & $40^{\prime}$ & 1,048 & 4.10 & $\$ 0.247$ & $\$ 0.441$ & $\$ 0.607$ \\
\hline & $45^{\prime}$ & 12 & 3.53 & $\$ 0.282$ & $\$ 1.360$ & $\$ 1.642$ \\
\hline & $60^{\prime}$ Artic & 18 & 2.70 & $\$ 0.291$ & $\$ 0.190$ & $\$ 0.481$ \\
\hline \multirow{6}{*}{$\begin{array}{l}\text { Diesel } \\
\text { Hybrid }\end{array}$} & Unknown & 15 & 4.72 & $\$ 0.098$ & $\$ 0.028$ & $\$ 0.126$ \\
\hline & $32^{\prime}$ & 1 & 6.99 & $\$ 0.339$ & $\$ 1.717$ & $\$ 2.056$ \\
\hline & $40^{\prime}$ & 64 & 4.46 & $\$ 0.151$ & $\$ 0.134$ & $\$ 0.285$ \\
\hline & $41^{\prime}$ & 13 & 4.72 & $\$ 0.142$ & $\$ 0.922$ & $\$ 1.064$ \\
\hline & $42^{\prime}$ & 29 & 4.38 & $\$ 0.181$ & $\$ 0.188$ & $\$ 0.369$ \\
\hline & $60^{\prime}$ Artic & 44 & 3.69 & $\$ 0.196$ & $\$ 0.445$ & $\$ 0.641$ \\
\hline Trolley & Unknown & 3 & 5.01 & $\$ 0.389$ & $\$ 0.148$ & $\$ 0.536$ \\
\hline Total Fleet & & 1,490 & & & & \\
\hline
\end{tabular}

* Miles driven by each bus are used as weights in calculating group averages. 
The use of weighted averages noticeably changes the results of the analysis, most notably for the 40-foot buses, reducing the differential in fuel and cost efficiency between diesel and diesel hybrid vehicles. The analysis reveals that 40 -foot hybrid buses demonstrate 8.6 percent better fuel mileage than comparable diesel buses when accounting for mileage driven (compared to 21.6 percent when miles driven are not considered). The weighted average analysis indicates that the differential in cost efficiency between hybrid and diesel power plants is also lower when accounting for miles driven. When weighted averages are used, 40-foot hybrid buses have 38.9 percent lower parts cost per mile than similar diesel buses (compared to 71.2 percent when using simple averages), and 69.7 percent lower maintenance costs per mile than diesel buses of the same size (compared to 87.4 percent when using simple averages). Figure 3-5 shows the comparison between 40-foot diesel and diesel hybrid buses, using weighted averages to calculate fuel mileage and costs per mile.

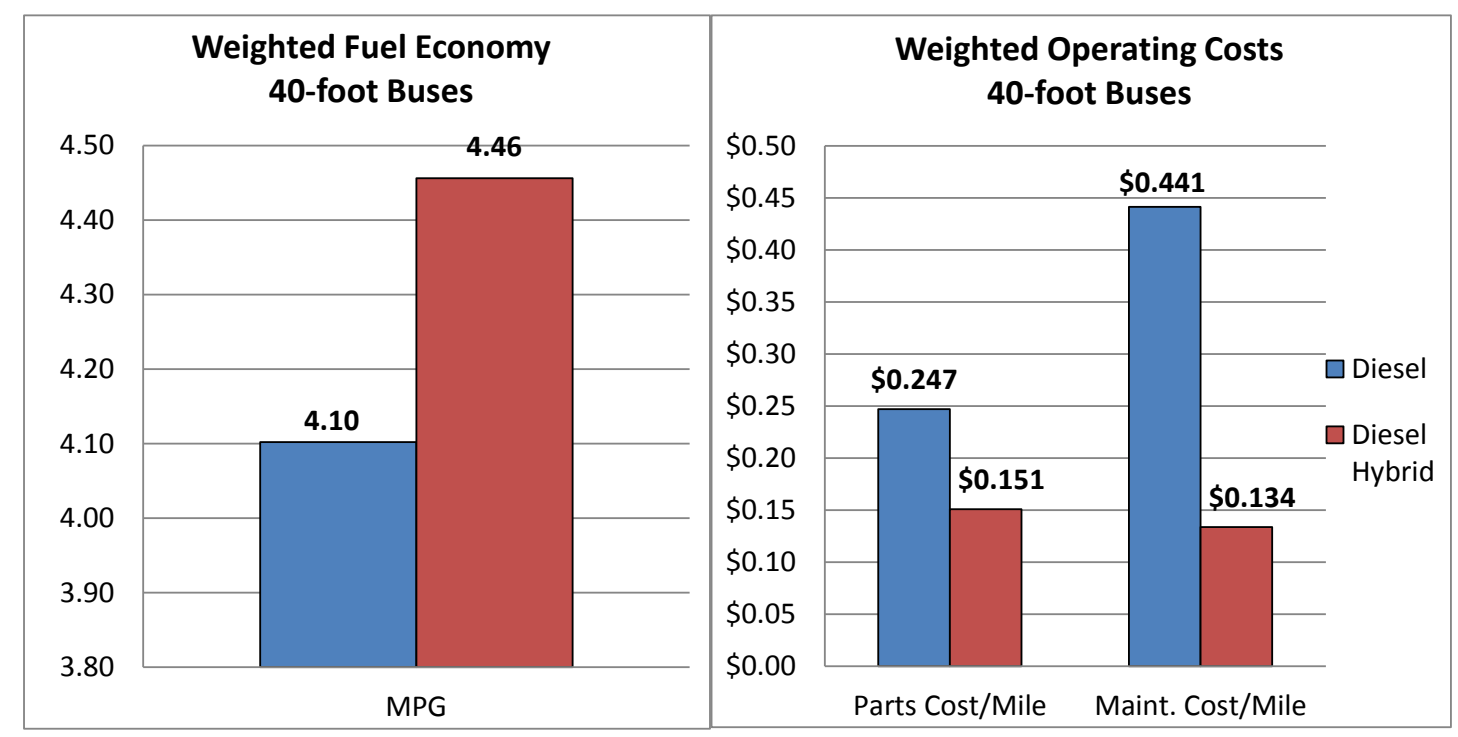

Figure 3-5. Weighted cost and performance comparison for 40-foot buses.

The data indicate that hybrid buses of sizes other than 40 -foot also perform better when compared to diesel buses. However, the differential in fuel mileage and cost efficiency is smaller when miles driven by each bus (i.e., weighted averages) are considered. Table 3-5 presents an aggregate analysis of the entire fixed route fleet using weighted average calculations.

Table 3-5. Fixed Route Aggregate Comparison - Weighted Parameters

\begin{tabular}{|l|r|r|r|r|r|}
\hline Power Plant & $\begin{array}{r}\text { Number } \\
\text { of Buses }\end{array}$ & $\begin{array}{c}\text { MPG } \\
\text { (Weighted)* }\end{array}$ & $\begin{array}{c}\text { Parts Cost } \\
\text { per Mile } \\
\text { (Weighted)* }\end{array}$ & $\begin{array}{c}\text { Maintenance } \\
\text { Cost per Mile } \\
\text { (Weighted)* }\end{array}$ & $\begin{array}{c}\text { Total Cost } \\
\text { per Mile } \\
\text { (Weighted)* }\end{array}$ \\
\hline Diesel & 1,321 & 4.11 & $\$ 0.247$ & $\$ 0.422$ & $\$ 0.601$ \\
\hline Diesel Hybrid & 166 & 4.47 & $\$ 0.153$ & $\$ 0.175$ & $\$ 0.328$ \\
\hline Trolley & 3 & 5.01 & $\$ 0.389$ & $\$ 0.148$ & $\$ 0.536$ \\
\hline Total Fleet & $\mathbf{1 , 4 9 0}$ & $\mathbf{4 . 1 4}$ & $\mathbf{\$ 0 . 2 4 0}$ & $\mathbf{\$ 0 . 4 0 0}$ & $\mathbf{\$ 0 . 5 8 1}$ \\
\hline
\end{tabular}

* Miles driven by each bus are used as weights in calculating group averages. 
The analysis shows that when accounting for miles driven, hybrid buses of any size generally have 8.7 percent better fuel mileage than diesel buses $(4.47 \mathrm{mpg}$ for diesel hybrid vs. $4.11 \mathrm{mpg}$ for diesel). Hybrid buses also have 38.0 percent lower parts cost per mile and 58.4 percent lower maintenance cost per mile than diesel buses. Figure 3-6 graphically demonstrates an aggregate comparison between diesel and diesel hybrid buses regardless of vehicle size, using weighted parameters.

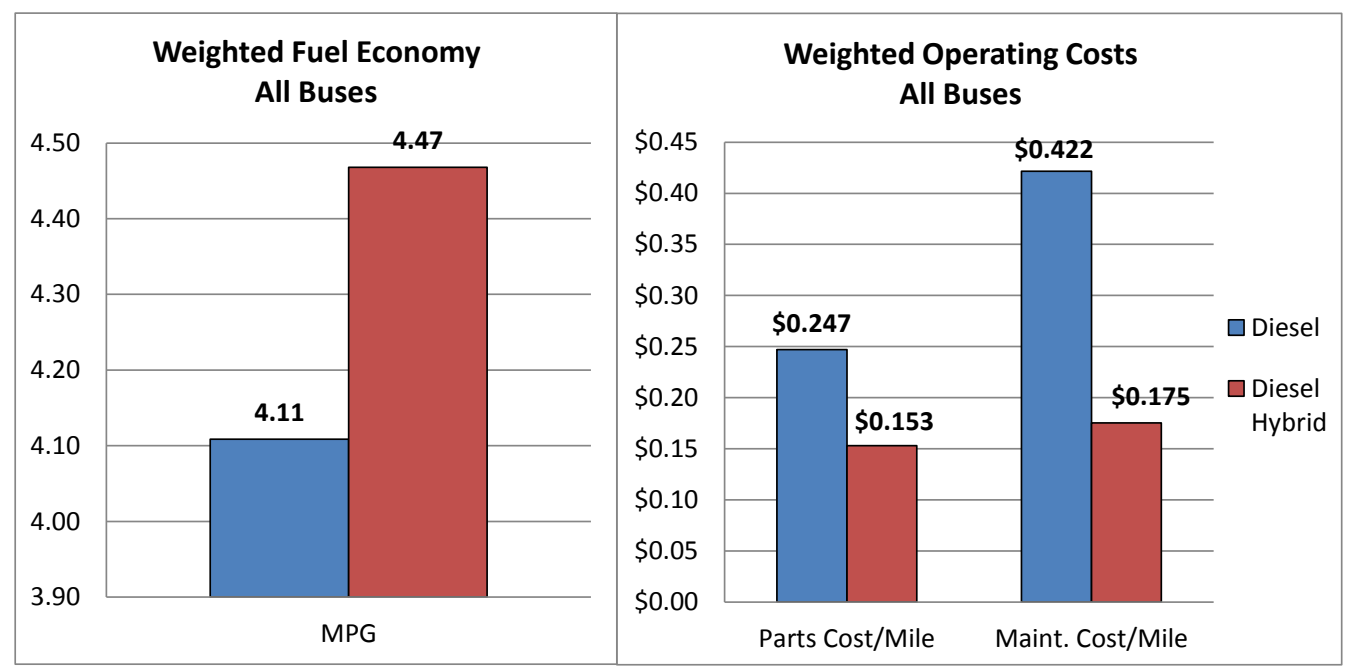

Figure 3-6. Weighted comparison - diesel vs. diesel hybrid buses of all sizes.

The observed results may indicate that a relatively large number of hybrid buses in the dataset are earlier-generation vehicles with lower fuel efficiency, which have been in use for some time and have logged a lot of mileage. The dataset also contains a large number of older, high-mileage diesel buses that perform exceptionally well. These two factors combined may reduce the difference between the (weighted) average fuel efficiency of a typical diesel hybrid bus and a typical diesel bus, when accounting for mileage driven. As newer, more efficient hybrid buses are driven more miles and the number of latergeneration hybrids in the dataset increases, the average fuel efficiency of hybrid buses will improve.

\section{Paratransit Fleet}

Table 3-6 presents the summary of aggregate performance and costs of paratransit vehicles. Vehicle acquisition costs have been adjusted to constant 2013 dollars using CPI.

Table 3-6. Comparison of Paratransit Vehicles with Different Power Plants

\begin{tabular}{|l|r|r|r|r|r|r|r|}
\hline $\begin{array}{c}\text { Power } \\
\text { Plant }\end{array}$ & $\begin{array}{c}\text { Number } \\
\text { of Buses }\end{array}$ & $\begin{array}{c}\text { Average } \\
\text { Age } \\
\text { (Years) }\end{array}$ & $\begin{array}{c}\text { Average } \\
\text { Acquisition } \\
\text { Cost }\end{array}$ & $\begin{array}{c}\text { Fuel } \\
\text { Mileage } \\
\text { (MPG) }\end{array}$ & $\begin{array}{c}\text { Parts } \\
\text { Cost per } \\
\text { Mile }\end{array}$ & $\begin{array}{c}\text { Maintenance } \\
\text { Cost per Mile }\end{array}$ & $\begin{array}{c}\text { Total } \\
\text { Operating } \\
\text { Cost per } \\
\text { Mile }\end{array}$ \\
\hline Unknown & 40 & 5.8 & & 7.65 & $\$ 0.159$ & $\$ 0.035$ & $\$ 0.194$ \\
\hline Diesel Hybrid & 2 & 3.6 & & 9.39 & $\$ 0.095$ & $\$ 0.030$ & $\$ 0.125$ \\
\hline Gasoline & 18 & 3.3 & $\$ 81,740$ & 7.63 & $\$ 0.127$ & $\$ 0.191$ & $\$ 0.318$ \\
\hline Total Fleet & $\mathbf{6 0}$ & $\mathbf{4 . 9}$ & $\mathbf{\$ 8 1 , 7 4 0}$ & $\mathbf{7 . 7 0}$ & $\mathbf{\$ 0 . 1 4 7}$ & $\mathbf{\$ 0 . 0 8 1}$ & $\mathbf{\$ 0 . 2 2 9}$ \\
\hline
\end{tabular}


Of the reported paratransit fleet, 3.3 percent ( 2 vehicles) are diesel hybrids and 30.0 percent are gasoline vehicles. The majority of the paratransit fleet (66.7 percent) did not report the power plant. All the reported paratransit vehicles are 25 -foot vehicles. The analysis indicates that hybrid paratransit vehicles demonstrate 23.1 percent better fuel mileage, 25.0 percent lower parts cost per mile, and 84.3 percent lower maintenance cost per mile than comparable gasoline-powered vehicles. Figure 3-7 presents the comparison of performance and operating costs between diesel hybrid and gasoline paratransit vehicles.

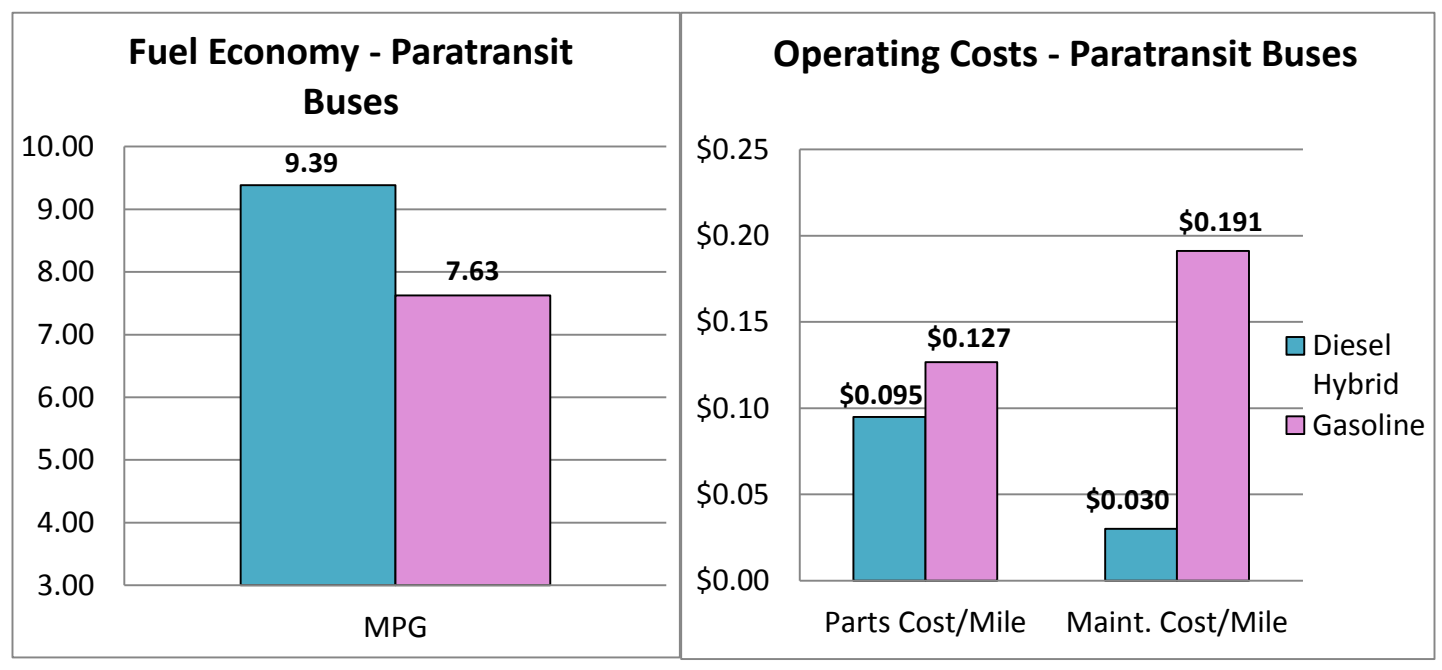

Figure 3-7. Comparison of diesel hybrid vs. gasoline paratransit vehicles.

Due to the limited amount of data reported, little further analysis could be performed for the demand response vehicles. As more paratransit data become available, the detail level of the analysis will improve. 


\section{Chapter 4 \\ Update of the Bus Fuels Evaluation Tool (BuFFeT) Model}

Bus Fuels Fleet Evaluation Tool (BuFFeT) model is a life-cycle cost model developed by the Center for Urban Transportation Research (CUTR) and previously funded by the Florida Department of Transportation (FDOT). This model was developed using detailed capital and operating cost data from almost 6,000 heavy-duty buses from transit fleets across the United States. The data in the model have not been updated since 2009, while the alternative transit technologies, as well as traditional diesel technologies, have advanced significantly, affecting both fuel efficiency and the costs of operating such technologies. Updating the model with current data is essential to keeping it useful to practitioners and decision-makers.

During 2013, CUTR researchers collected detailed operations and maintenance cost data from Florida transit agencies, covering over 1,600 heavy-duty transit vehicles. To update the model, the data collected from Florida agencies was added to the original data set, used to calculate model parameters. Only the vehicles that were 12 years or younger were considered, while vehicles that were 13 years or older as of 2013 were removed from the data set. This resulted in a combined data set of over 5,000 buses that was used for estimating model parameters. Group averages for buses of different power plants, calculated from the data, were then entered as default parameters into the BuFFeT model.

Available data allowed to update the following model parameters: average acquisition cost, fuel efficiency, average annual miles driven, labor cost per mile and parts cost per mile for diesel, biodiesel, compressed natural gas (CNG), liquefied natural gas (LNG), diesel hybrid and gasoline hybrid buses. All dollar amounts (acquisition cost, labor cost per mile, and parts cost per mile) were adjusted using consumer price index (CPI) and presented in constant 2013 dollars. Other parameters that could not be updated with current data remained unchanged in the updated model. 


\section{Chapter 5 \\ Preparation for Alternative Fuel Bus Clearinghouse}

As part of the effort to establish a National Alternative Fuel Bus Clearinghouse, CUTR developed the Advanced Transit Energy Portal (ATEP) website, a single-point source of information related to the operation of alternative fuel vehicles and technologies in the U.S. transit fleet. The website provides up-to-date articles and features the latest developments in various alternative fuel transit technologies, transit agency news, and U.S. transit agencies' experience with operating alternative fuel vehicles in their fleets, including identified advantages and limitations, lessons learned, best practices and critical success factors, and research results.

CUTR has secured the domain name www.advancedtransitenergy.org for the ATEP website. While some features of site are still under construction, the information dissemination portion has been live and operational since October 2013. Funded by supplemental federal NCTR sources, this effort closely relates to the initiatives undertaken for this project. Appendix A presents a screen shot of the front page of the ATEP website.

In addition to information exchange, the ATEP website can serve as a host for collecting data on the performance and operations of various alternative fuel vehicles in the U.S. transit fleet. For that purpose, CUTR is developing a formalized online data collection tool that will allow transit agencies to input their fleet performance and cost data electronically.

Researchers are working with APTA leadership and individual members to develop a simple but comprehensive data collection format that will encourage agency acceptance and participation. CUTR also identified an active group of transit agencies known as the American Bus Benchmarking Group (ABBG), which expressed interest in the data collection tool, is willing to provide expertise with testing the final product, and can assist in reaching out to transit agencies across the U.S. Appendix A presents the proposed sample data collection template, with completion instructions.

Once completed, this electronic data submission tool will be integrated with the ATEP website and is expected to facilitate collecting data from transit agencies nationwide, as well as improve their participation and reporting regularity in the future. 


\section{Chapter 6 \\ Challenges and Limitations}

The greatest challenge in performing the analysis was related to the availability of data. Only eight of the Florida fixed route transit agencies provided data on the performance and costs of their fleet, and no out-of-state agencies reported data. Reporting consistency was another problem. Of the eight reporting agencies, only one reported data every quarter in 2013, four agencies reported almost every quarter, and the remaining three agencies provided data only in some quarters throughout the year.

The collected data revealed a limited number of alternative fuel vehicles in the surveyed transit fleet. Of the 1,490 fixed route vehicles reported to CUTR in 2013, only 166 (or 11.1 percent) were alternative fuel vehicles. The low number of observations limits the reliability of the analysis, and should be interpreted with caution. In addition, the data showed a lack of variety in the alternative propulsion technologies used by the surveyed transit agencies. The only alternative propulsion technology reported by the agencies (if at all) was diesel hybrid. Therefore, it was not possible to compare performance between multiple alternative technologies on the market. The only comparison that could be made from the reported data was between diesel and diesel hybrid vehicles.

While the amount of data on the fixed route fleet was more or less adequate, CUTR did not obtain a significant-size sample for demand response vehicles. The paratransit fleet data reported to CUTR covered only 60 demand response vehicles. In addition, complete and consistent data were available for only 17 paratransit vehicles. With such a small data sample, it was practically unfeasible to make any reliable estimates regarding the life cycle costs of operating alternative fuel paratransit vehicles.

The above challenges limited the amount and the reliability of the analysis that could be performed on this project. The results presented in this report should be treated with caution, recognizing that the analysis was based on a limited amount of data. As more data on the performance and maintenance costs of alternative fuel vehicles become readily available, the reliability and robustness of the analysis will improve. 


\section{Chapter 7 \\ Conclusions and Suggestions}

While CUTR collected valid operating and maintenance cost data for the majority of Florida's fixed route transit fleet, no data was obtained from out-of-state transit agencies. All the analysis presented in the current report is based on Florida transit fleets. The data analysis for fixed route buses revealed that majority of transit buses in Florida are regular diesel buses ( 89 percent of the reported fleet), while only 11 percent are alternative fuel vehicles (diesel hybrids). More than 79 percent of the diesel buses are 40-foot buses, with 35-foot and 32-foot buses representing 6.8 percent and 6.3 percent of the diesel fleet, respectively. Alternative fuel buses, on the other hand, are more likely to be larger in size than diesel buses. Sixty-foot articulated buses represent 26.5 percent and 40 -foot buses account for 38.6 percent of the diesel hybrid fleet.

The analysis of fixed route data showed that alternative fuel buses have significantly higher acquisition costs but offer better fuel mileage than diesel buses. In addition, hybrid buses tend to have lower parts costs and maintenance costs per mile than comparable diesel buses. A 40-foot diesel hybrid bus has 21.6 percent better fuel economy $(4.45 \mathrm{mpg}$ for hybrid vs. $3.66 \mathrm{mpg}$ for diesel), 71.2 percent lower parts cost per mile ( $\$ 0.120 / \mathrm{mile}$ for hybrid vs. $\$ 0.417 /$ mile for diesel), and 87.4 percent lower maintenance cost per mile ( $\$ 0.124 /$ mile for hybrid vs. $\$ 0.985$ for diesel) than a regular diesel bus. At the same time, a 40 -foot diesel hybrid bus costs 66.2 percent more to acquire than a comparable diesel bus.

The aggregate comparison of performance and maintenance costs of traditional diesel and hybrid buses operated by Florida fixed route agencies revealed that hybrid buses, regardless of vehicle size, have 21.0 percent better fuel economy, 66.2 percent lower parts cost per mile, and 72.2 percent lower maintenance cost per mile, compared to diesel buses. However, hybrid buses on average cost 67.0 percent more than traditional diesel buses. Average vehicle age contributes at least partially to the performance differential. An average diesel hybrid bus in the current analysis is 2.9 years old, compared to 8.4 years for an average diesel bus. Newer buses typically perform better and cost less to operate and maintain. Additionally, unlike diesel buses, most of the hybrid buses were still under the original manufacturer's warranty, reducing possible repair costs.

Surprising results were observed when weighted averages were used to calculate miles per gallon and cost per mile in order to account for potential differences in miles driven by different buses in the data sample. The use of weighted averages noticeably changes the analysis results, most notably for the 40 -foot buses, reducing the differential in fuel and cost efficiency between diesel and diesel hybrid vehicles. When accounting for miles driven, 40-foot hybrid buses demonstrate 8.6 percent better fuel mileage (compared to 21.6 percent when miles driven are not considered), 38.9 percent lower parts cost per mile (compared to 71.2 percent when using simple averages), and 69.7 percent lower maintenance costs per mile (compared to 87.4 percent when using simple averages) than diesel buses of the same size. 
The observed results may indicate that a relatively large number of hybrid buses in the dataset are earlier-generation vehicles with lower fuel efficiency, which have been in use for some time and have logged a lot of mileage. The dataset also contains a large number of older, high-mileage diesel buses that perform exceptionally well. As newer, more efficient hybrid buses are driven more miles and the number of later-generation hybrids in the dataset increases, the average fuel efficiency of the hybrid buses will improve.

In addition to the fixed route vehicles, CUTR collected a limited data sample on the paratransit fleet, covering 60 demand response vehicles over the course of this project. Thirty percent of the demand response fleet consists of gasoline-powered vehicles, 3.3 percent ( 2 vehicles) are diesel hybrids, and the power plant of the remaining 66.7 percent of the paratransit fleet is not known (i.e., was not reported). The available data indicate that hybrid paratransit vehicles demonstrate 23.1 percent better fuel mileage, 25.0 percent lower parts cost per mile, and 84.3 percent lower maintenance cost per mile than comparable gasoline-powered vehicles. Due to the extremely small data sample and significant gaps in the paratransit data, the extent of the analysis as well as the reliability of the comparison are far from optimal.

The intent of the current analysis was to contribute to the ongoing evaluation of the costs and benefits of investment in advanced transit technologies, rather than to provide recommendations on the choice of a particular alternative fuel technology. No attempt was made to provide a comprehensive comparative analysis of the existing advanced transit technologies, and the results should be treated accordingly. Additionally, since the analysis was based only on a relatively small data sample, the reliability may not be particularly high, and the results of the analysis should be treated with caution.

It is suggested to continue collecting data from transit service providers on the performance and life cycle costs of alternative fuel vehicles. As more field data are collected, the reliability of the analysis will improve.

To encourage agencies to submit data regularly, it is recommended to consider incorporating this data reporting requirement into the existing nationwide transit data collection efforts, such as the Public Transportation Vehicle Database implemented by APTA and/or the National Transit Database maintained by FTA.

It is also recommended to implement an online data collection tool that would facilitate regular data submission by transit agencies and simplify storage, handling, and analysis of the data. 


\section{Appendix A}

\section{Data Collection Templates and ATEP Website}

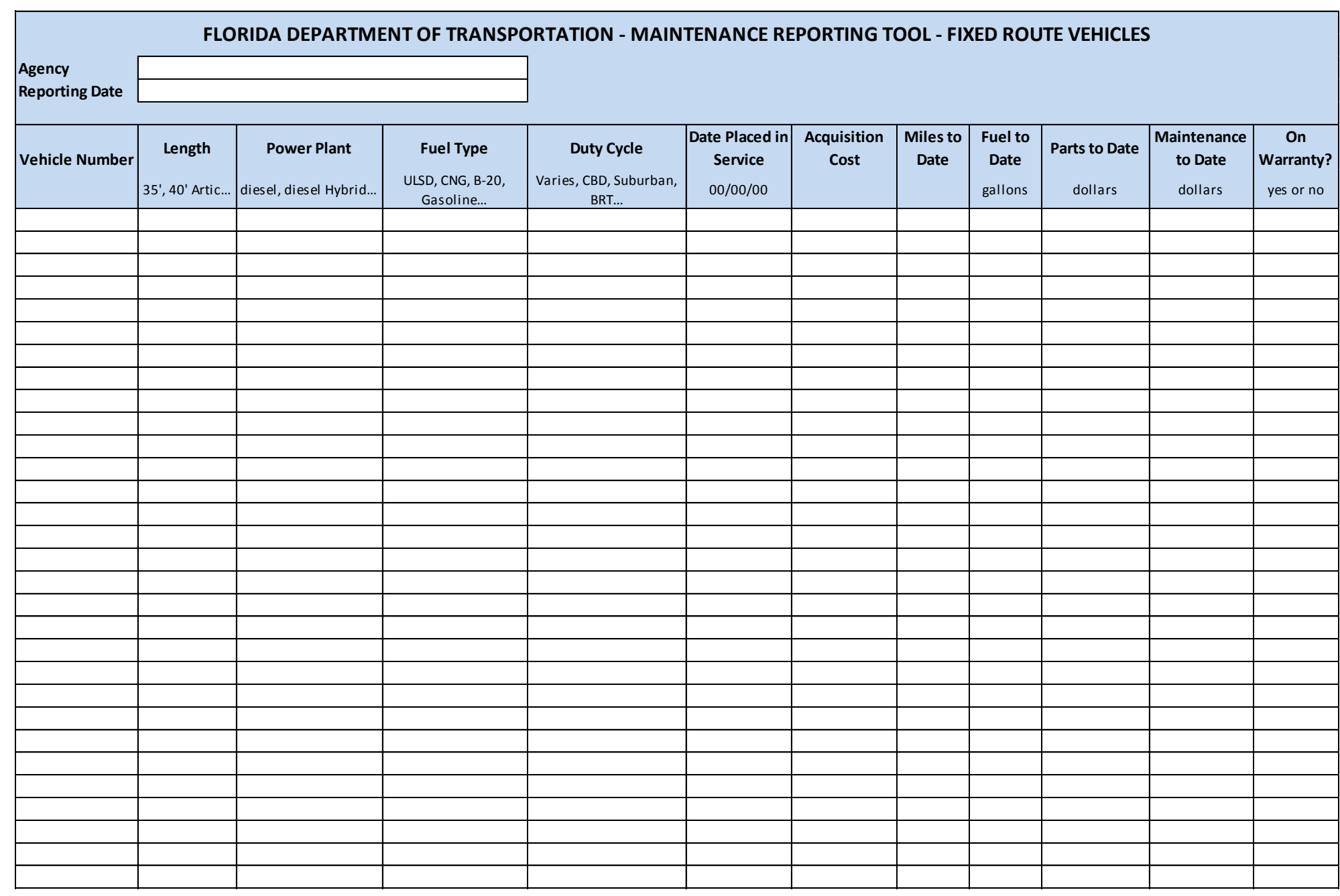

Figure A-1. Fleet data collection template. 


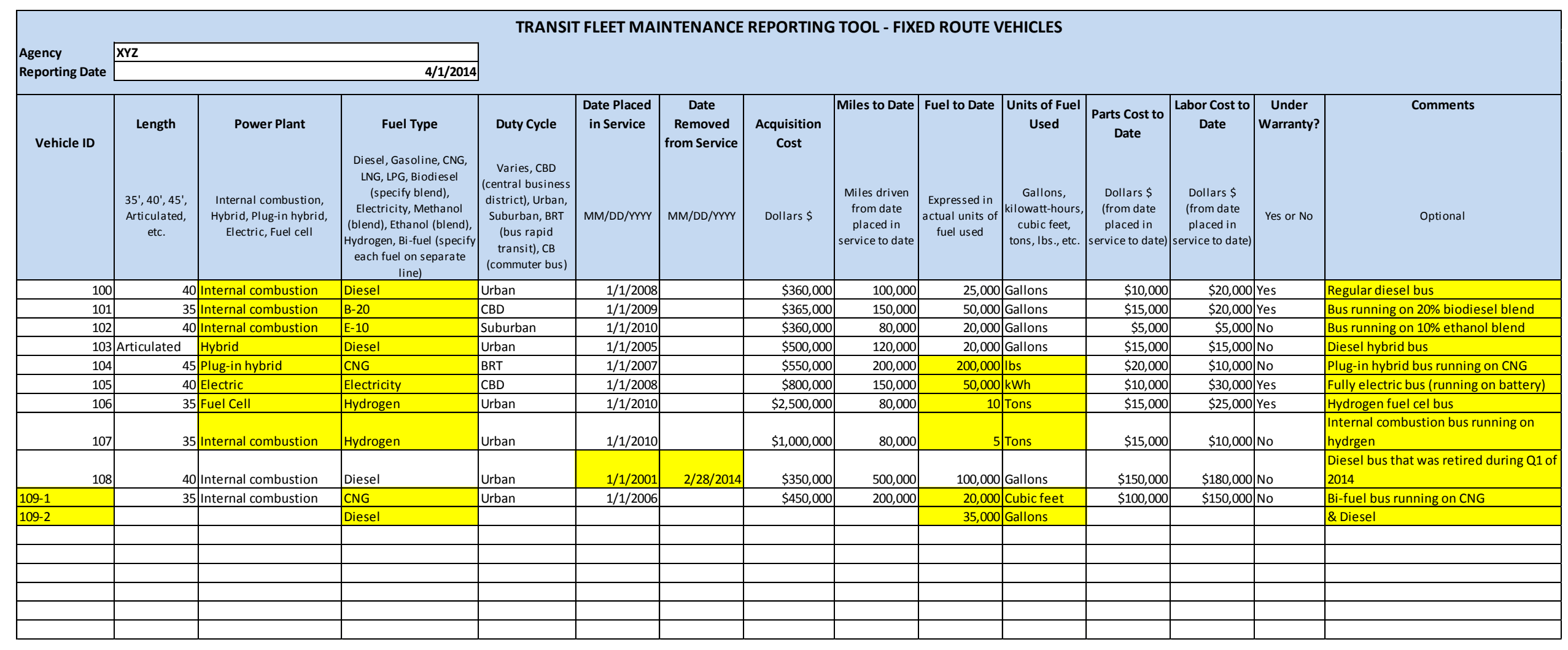

Figure A-2. Proposed ATEP sample data collection page. 
The Volvo Group

Studies Potential to

Test Electric Roads in

a city

The Volvo Group is now taking the next step in the development of sustainable transport solutions. In collaboration with the Swedish Transport Administration, the Volvo Group will study the potential for building electric roads, where city buses can be charged.

Read more

8 ate123 ๑28 May 2014

文 Industry News

$\mathbb{E}$ Edit this pos:

New Flyer Nets

Translink Fleet

Contract for Natural

Gas Buses

The South Coast British Columbia Transportation Authority, known as TransLink, has placed an order with New Flyer Industries Inc. for 45 Xcelsior compressed natural gas (CNG) 40 -foot buses. The contract also includes options
Altoona Testing of

First 40-foot,

Zero-Emissions

Electric Rapid Transit Bus is Complete

The Altoona Bus Research and Testing Center under the Larson Institute and sponsored by the Federal Transit Administration (FTA), last week completed the FTA's "new model bus testing program" of the first 40-foot, all-electric bus. The BYD Electric Bus has successfully completed the Altoona structural integrity testing program in a...

Read more

8 ate123 ๑28 May 2014

Бे Industry News

$\mathbb{E}$ Edit this post

the tor his post

Collins Begins Selling Westport-Equipped CNG Buses

Collins Bus Corp. says it is now taking orders from fleet managers for its new Type A school bus featuring a compressed natural gas (CNG) fuel system. The vehicle is built
STA giving all-electric buses a tryout

A shiny, new, all-electric Chinese bus is running on Spokane routes this month under a special demonstration through a U.S. branch of BYD Co. Ltd. Spokane Transit Authority was invited to test the zero-emission bus as part of a statewide.

Read more,

2 ate123 @20 May 2014

$\bar{D}$ Agency News, Industry News

$\mathbb{E}$ Edit this post

Partners Working On Full-Size Fuel Cell Hybrid Bus

Ballard Power Systems has signed an agreement with CALSTART, a nonprofit organization focused on clean transportation activities, to deploy a fuel cell hybrid bus at the University of California campus in Irvine. BAE Systems and EIDorado National are also participating.

Read more ,
Development of an On-Board H2 Storage And Recovery System Based On Lithium Borohydride

Development of an On-board H2 Storage and Recovery System Based on Lithium Borohydride Submitted to: Center for Transportation and Materials Engineering, Youngstown State University By: Clovis A. Linkous STEM College professor Department of Chemistry Youngstown State University phone: (330) 941-1958

Read more ,

8 ate123@20 May 2014

犃 Research Results

$\mathbb{E}$ Edit this post

N.Y. MTA testing solarpowered kiosks that provide real-time info

The MTA, Metro-North Railroad and New York City Transit are testing the performance and reliability of solar-powered kiosks that allow customers to access real-time train, subway

Figure A-3. Screen shot of ATEP website. 